\title{
Reference evapotranspiration prediction using neural network method
}

\section{Predicción de evapotranspiración de referencia utilizando redes neuronales Artificiales}

\author{
AGUSTÍN-RAMÍREZ Marco, A.†*, EL HAMZAOUI, Youness and RUZ-HERNÁNDEZ, José A. \\ Universidad Autónoma del Carmen, México
}

ID $1^{\text {st }}$ Author: Agustín-Ramírez, Marco A. / ORC ID: 0000-0002-4397-1515, CVU CONACYT ID: 1015115

ID 1st Coauthor: El Hamzaoui, Youness / ORC ID: 0000-0001-5287-1594, CVU CONACYT ID: 292367

ID $2^{\text {nd }}$ Coauthor: Ruz-Hernández, José A. / ORC ID: 0000-0001-8332-4980, CVU CONACYT ID: 216374

DOI: $10.35429 / J O I E .2021 .16 .5 .16 .24$

Received March 13, 2021; Accepted June 30, 2021

\begin{abstract}
Water is the most vital resource for life on earth, At present we know that irrigation systems have currently acquired great importance due to the scarcity that is affecting worldwide, since there is no awareness about this important resource, however, for years we have worked to try to solve this problem. The objective of this research work was to develop a Feedforward Backpropagation type neural network algorithm with three layers: in the input layer include the operating factors such as the maximum temperature $\left({ }^{\circ} \mathrm{C}\right)$, the minimum temperature $\left({ }^{\circ} \mathrm{C}\right)$, the average temperature $\left({ }^{\circ} \mathrm{C}\right)$ and solar radiation $(\mathrm{mm} /$ day) and the hidden layer three neurons and yet in the output layer only one neuron, this algorithm has been trained by the Levenberg-Marquardt algorithm to predict the evapotranspiration. The results were satisfactory because the algorithm was able to predict the reference evapotranspiration with a correlation coefficient of $99.99 \%$ and with an error of 0.0001 . Therefore, this technique can be considered to automate the online irrigation system by monitoring plant transpiration and soil evaporation.
\end{abstract}

Artificial Neural Networks, Irrigation System, Evapotranspiration

\section{Resumen}

El agua es el recurso más vital para la vida en la tierra, en la actualidad sabemos que los sistemas de riego han adquirido actualmente gran importancia debido a la escasez que está afectando a nivel mundial, ya que no existe conciencia sobre este importante recurso, sin embargo, desde hace años hemos trabajado para tratar de solucionar este problema. El objetivo de este trabajo de investigación fue desarrollar un algoritmo de red neuronal tipo Feedforward Backpropagation con tres capas: en la capa de entrada incluyen los factores de funcionamiento como la temperatura máxima $\left({ }^{\circ} \mathrm{C}\right)$, la temperatura mínima $\left({ }^{\circ} \mathrm{C}\right)$, la temperatura media $\left({ }^{\circ} \mathrm{C}\right)$ y la radiación solar(Rs) (mm/día) y la capa oculta tres neuronas y sin embargo en la capa de salida solo una neurona, este algoritmo ha sido entrenado mediante el algoritmo de Levenberg-Marquardt para predecir la evapotranspiración. Los resultados fueron satisfactorios debido a que el algoritmo ha sido capaz de predecir la evapotranspiración de referencia con un coeficiente de correlación del 99,99\% y con un error de 0,0001 . Por lo tanto, esta técnica se puede considerar para automatizar el sistema de riego en línea mediante el monitoreo de la transpiración de las plantas y la evaporación del suelo.

Redes Neuronales Artificiales, Sistema de riego, Evapotranspiración

Citation: AGUSTÍN-RAMÍREZ Marco, A., EL HAMZAOUI, Youness and RUZ-HERNÁNDEZ, José A. Reference evapotranspiration prediction using neural network method. Journal of Innovative Engineering. 2021. 5-16: 16-24

\footnotetext{
*Correspondence to Author (e-mail: marck_hego@hotmail.com).

$\dagger$ Researcher contributing as first Author.
} 


\section{Introducción}

Agriculture is a sector with great importance in our country, however at present there are three problems that are strongly linked to each other, First the excessive growth of the population, according to census conducted by INEGI there is an (POBLACION, 2020) estimated population for the current year of 127 billion inhabitants only in Mexico, the second as it is due to greater demand in the production of food of agricultural origin, of basic (Agricultura, 2020)basket such as (white corn, tomato, rice, beans) due to that increase in population and third climate change; according to statistical data worldwide there is a trend in the rise of temperatures around the world and a decrease in the amount of annual precipitation, as a consequence, there has been a decrease in water resources (Diaz Cordero, 2012)worldwide. According to the research carried out by (Conagua, 2018)in figure 1 se shows a graph the use of water by sector, in it can be seen that in the agricultural sector the use of this resource exceeds $70 \%, 4.72 \%$ is used to generate electricity, $4.86 \%$ is used for industry and $14.38 \%$ is used for public supply, the scarcity of water worldwide makes it necessary to develop alternatives to make water use more efficient and implement irrigation systems that regulate its consumption.

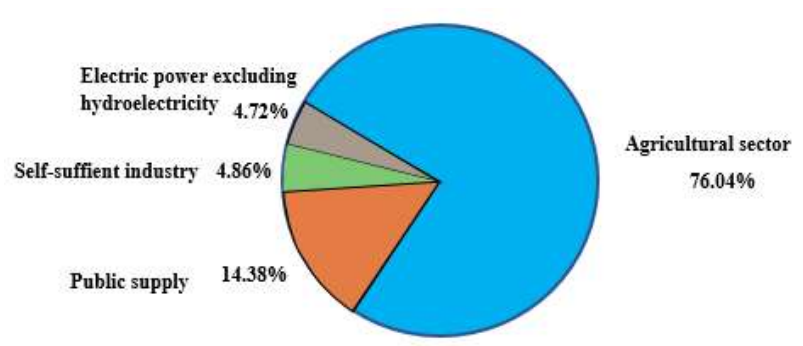

Figure 1 Consumption by sector Source (CONAGUA 2., 2020)

The Food and Agriculture Organization of the United Nations(FAO) has carried out numerous investigations, to find a method by means of meteorological variables to determine a method that is the most optimal for the estimation of the reference evapotranspiration, most of the methods overestimated the desired values of the ETo as is the case of the PenmannMonteith equation.

The other equations demonstrated a variable correlation with respect to the evapotranspiration of the standard reference crop (grass).
As a result of the results obtained by FAO, FAO concluded that the PenmannMonteith method was the best option for irrigation planning for up to one year but needed local wind adjustment to achieve satisfactory results. In 1981 George H. Hargreaves and his collaborators presented in a published empirical equation that uses only maximum temperatures, and minimum and average air temperatures in the absence of missing meteorological data, for the calculation of the water needs of crops. The tests provided very good results of the ETo; these results generated the confidence of being applied under different geographical regimes at a global level.

Evapotranspiration is a combination of two separate processes by means of which water is lost through the soil surface due to the incidence of solar radiation on this surface and the transpiration of the crop, evaporation is the process by which water in liquid state becomes water vapor and is removed from the surface, to change between one state and another, so energy is required to generate the transition from one state to another, this is where direct solar radiation intervenes, such that to a degree that increases the temperature of the environment will raise the Evapotranspiration values.

There is a lot of research focused on developing irrigation systems. (García , Parra, Jimenez, Lloret, \& Lorentz, 2020) Irrigation systems ranging from wireless sensor network systems for climate monitoring, PH monitoring, soil moisture monitoring, soil nutrient monitoring, as well as to the development of complex machine learning algorithms the ANFIS, Bayesian network, classification and regression trees, Deep Neural Networks, and ANNs are examples of machine learning algorithms to name a few.

Artificial neural networks are described as mathematical models used to approximate functions as complex as it is in the case of ETo that is considered non-linear in nature that depends on temperature, relative humidity, wind speed and mainly solar radiation. The approximation of a nonlinear function consists of finding, by means of a training algorithm, a vector of parameters that, together with a linear combination with the vector of input variables, minimizes the mean square error between the responses of the model and the desired responses observed. 
The most used networks to generate this type of model is the feedforwardback propagation type, where the neurons of each layer connect "forward" from the input layer to the hidden layer to the output layer. The first layer allows to approximate a function either linear or nonlinear of one or more variables around a set of input variables and the second layer allows to predict the temporal behavior in function of the set of variables of the input layer (Gonzalez-Camacho, 2008).

The following are the works most related to this research such as:

(Cervantes-Osornio, 2013) who in his research carried out the evaluation of 4 empirical models such as the Hargreaves, Hargreavescalibrated and the Pristley-taylor with the model of radial-based neural networks with the same input variables, taking as reference to estimation of the Eto recommended in FAO 56, thus using data from 4 four climatic stations located in different locations, concluded that for the Hargreaves method tends to overestimate the evapotranspiration values.

(O. Lucas, 2018)He developed a neural network of type Feedforward back propagation using 3 input parameters: such as maximum temperature, minimum temperature and day, in the hidden layer I use 10 neurons, and a neuron in the output layer, at the time of validating the results he found that the RNA is able to obtain values close to the standard, that is to say it showed an adjustment with an accuracy of $85 \%$ Penmann-Monteith model, he proved that the RNA method, using Levenberg-Marquad is recommended to predict the reference evapotranspiration, however it is not enough to affirm the optimal use of water in irrigation systems.

The objective of this research was to perform a Feedforward Backpropagation (FFBP) type neural network model with 99.99\% efficiency, trained with Levenberg-Marquad to predict reference evapotranspiration (ETo), from historical records of solar radiation, maximum temperatures, minimum temperatures, average temperature, to evaluate its performance and predictability at a day interval. Undoubtedly, with these results this model has a lot of potential in terms of predicting and estimating the amount of water required by a crop.
The introduction section briefly presents the background of the problems addressed in this work, as well as the methods used and the results obtained in similar research carried out on this problem. The methodology section explains the concept and theory of neural networks, details the process that was carried out for the implementation of the proposed model. The results and discussion section consists of the results obtained by comparing the experimental data and the simulated data and the approximation made by the proposed model. The acknowledgments section introduces the institutions involved that supported this study. Finally, the conclusion and references sections of the work are presented.

\section{Materials and methodology}

\subsection{Geographical description}

The study was conducted in southeastern Mexico in the municipality of Ciudad del Carmen, Campeche, since the hot season lasts 5 months, from April 23 to September 24, the average daily maximum temperature is more than $31^{\circ} \mathrm{C}$. The hottest day of the year is June 20 , with an average maximum temperature of $32^{\circ} \mathrm{C}$ and an average minimum temperature of $26^{\circ} \mathrm{C}$. The cool season lasts 2.4 months, from December 2 to February 12, and the average daily maximum temperature is less than $28^{\circ} \mathrm{C}$. The coldest day of the year is January 17, with an average minimum temperature of $21^{\circ} \mathrm{C}$ and an average maximum of $27^{\circ} \mathrm{C}$. Campeche located at latitude 18.2672, and Longitude: $91.800118^{\circ} 16^{\prime} 2^{\prime \prime}$ North, $91^{\circ} 48^{\prime} 0^{\prime \prime}$ West; the average multi-year rainfall fluctuates from 22 $\mathrm{mm}$ to $255 \mathrm{~mm}$, the average annual temperature from 22.8 to $28.5{ }^{\circ} \mathrm{C}$, the potential evapotranspiration (ETP) from 1100 to $2150 \mathrm{~mm}$ and altitude of $4 \mathrm{~m}$.

The daily climatological data of input model for the prediction of evapotranspiration were obtained from the meteorological station located in Ciudad del Carmen that belongs to the network of automatic meteorological stations of CONAGUA (EMAS) located at 11.7 meters of altitude, $18^{\circ} 39^{\prime} 29^{\prime \prime}$ latitude and $91^{\circ} 45^{\prime}$ 55" longitude. These data were preprocessed at a daily level, (CONAGUA S. , 2020) which covered the period January 1926 to December 2018. 
The dataset from January 1926 to December 2018 (20111 days), once the data was obtained, was classified as can be seen in Table 1 , the data were used for the calculation of evapotranspiration $\left(\mathrm{ET}_{\mathrm{o}}\right)$ using the Hargreaves model, as well as in the training, validation and testing of the ANNs, $70 \%$ of the data and $30 \%$ of the data were used to perform the validation of the model. The data was preprocessed into spreadsheets and software used for neural network training for MATLAB version 2017. The variables of Measurement date, time of year, maximum temperature, minimum temperature, average temperature, solar radiation, were used as input parameters.

\begin{tabular}{|l|r|r|r|r|r|r|}
\hline Date & \multicolumn{1}{c}{ Season } & $\mathbf{T}_{\max }$ & $\mathbf{T}_{\min }$ & $\mathbf{T}_{\text {med }}$ & $\mathbf{R}_{\text {s }}$ & $\mathbf{E T}_{\text {or }}$ \\
\hline 9832 & 0.3 & 28 & 22 & 25 & 0.02507 & 2.63 \\
\hline 9833 & 0.3 & 28.2 & 21.5 & 24.85 & 0.02507 & 2.77 \\
\hline 9834 & 0.3 & 26.5 & 21.5 & 24 & 0.02507 & 2.34 \\
\hline 9835 & 0.3 & 26.1 & 20.4 & 23.25 & 0.02507 & 2.46 \\
\hline 9836 & 0.3 & 26.2 & 21.9 & 24.05 & 0.02507 & 2.17 \\
\hline 9837 & 0.3 & 28.3 & 21.4 & 24.85 & 0.02507 & 2.81 \\
\hline 9838 & 0.3 & 26 & 22.4 & 24.2 & 0.02507 & 2.00 \\
\hline
\end{tabular}

Table 1 Data sample with input variables for training, validation of Red Neuronal

Source: (CONAGUA S, 2020)

\subsection{Data Processing}

A 21111 set of data referring to 95 years was used, from January 1926 to December 31, 2018, the entries were selected: time of year, date, $T_{\max }, T_{\text {med }}, T_{\min }, R_{s}$, respectively, the time of year in a range by season assigning it a range of [0.1$0.4]$, respectively for each season of the year. spring, summer, autumn winter, the date was converted into category format to numerical the data were normalized, the data of extraterrestrial solar radiation tabulated in. (Allen, 1998) Then we proceeded to normalize the data with the normalization formula: (Despange \& Massart, 1998) .

$x_{i}=0.8\left(\frac{x_{i}-x_{\min }}{x_{\max }-x_{\min }}\right)+0.1$

\subsection{Evapotranspiration estimation}

\subsubsection{Hargreaves method}

The Hargreaves method is an empirical method considered in many studies because it is a method applicable to various geographical areas. This method is largely used for its great accuracy in daily irrigation plans.
The Hargreaves equation, proposed by is written as: (G.H \& Z. A, 1985)

ETo $=0,0023 \cdot R_{s}\left(T_{m}+17,8\right) \cdot\left(T_{\text {máx }}-T_{\text {mín }}\right)$

Where:

$\mathrm{ET}_{\mathrm{o}}=$ reference evapotranspiration, expressed in $\mathrm{mm} /$ day.

$\mathrm{R}_{\mathrm{S}}=$ extraterrestrial solar radiation, expressed in $\mathrm{mm} /$ day. (Allen,1998)

$\mathrm{T}_{\text {med }}=$ average daily temperature, understood as the average of the maximum temperature and the minimum temperature of the period, expressed in ${ }^{\circ} \mathrm{C}$.

$\mathrm{T}_{\max }=$ maximum daily temperature, expressed in ${ }^{\circ} \mathrm{C}$.

$\mathrm{T}_{\min }=$ minimum daily temperature, expressed in ${ }^{\circ} \mathrm{C}$. (FAO, 1977)

\subsubsection{Artificial Neural Networks Method}

Neurons are grouped into different layers and interconnected according to a certain architecture, as in nature, the network function is largely determined by the connections between its elements (neurons), each connection between two neurons has a weight coefficient. The feed network often has one or more hidden layers of sigmoid neurons, followed by an output layer of linear neurons, several layers of neurons with nonlinear transfer functions that allow the network to learn the linear and nonlinear relationships between the input vector and the output vector. The linear output layer allows the network to produce values within the range of 1 to +1 . ( Aleboyeh, Kasiri, \& Olya, 2011). For the network, notation is used in a two-layer network, (Limin, 1994)

The number of neurons in the input layer and the output layer are determined respectively by the number of inputs and output variables.

$n_{1}=w_{i(1.1)} l n_{1}+w_{i(1,2)} l n_{2}+\cdots+w_{i(1, k)}$

In this research work, a backpropagation type network has been proposed, where the input layer consists of nine variables (time of year, measurement date, maximum temperature, minimum temperature, average temperature, solar radiation). The optimal number of neurons in the hidden layer(s) is difficult to specify and depends on the type and complexity of the process. 
This number is usually determined iteratively. Each neuron in the hidden layer has a bias b (threshold), which is added to the weighted inputs to form the neuron $n$ equation (1). This sum, $n$, is the argument of the transfer function $\mathrm{f}$. The coefficients associated with the hidden layer are grouped into matrices (weights) and (biases). The output layer calculates the weighted sum of the signals provided by the hidden layer, and the associated coefficients are grouped into matrices and $b$. Using matrix notation, the output of the any can be given by: $w_{i} b_{1} w_{o}$ Equation (2):

out $=g\left(w_{o} * f\left(w_{i} * \ln +b_{1}\right)\right)$

Neurons in the hidden layer can use any differentiable transfer.

Function to generate its output. In this work, a hyperbolic tangent sigmoid transfer function (TANSIG) in the hidden layer with six neurons and a linear transfer function (PURELIN) in the output layer were used for $\mathrm{f}$ and $\mathrm{g}$, respectively. The system adjusts ( H. \& Beale, 2001) the weights of the internal connections to minimize errors between the hidden layer of the network and desired output, which can be summarized as follows: it first takes a random number group as initial values of the weights $(\mathrm{w})$ and the $w$ bias (b), then calculates the output of all neurons layer by layer, starting with the input layer using the following equations:

$$
\begin{aligned}
& f=\operatorname{tansig}\left(w_{i} * \ln _{k}+b_{1 s}\right) \\
& f=\frac{2}{1+e^{-2 *\left(w_{i} * \ln n_{k}+b_{1 s}\right)}} \\
& g=\operatorname{purenlin}\left(\mathrm{w}_{\mathrm{o}} \times \mathrm{f}+\mathrm{b}_{1 \mathrm{~s}}\right) \\
& g=\text { Out }
\end{aligned}
$$

If the transfer functions are considered, in equation (4), it can be expressed as follows:

Out $=\operatorname{purelin}\left(\mathrm{w}_{\mathrm{o}} \times\left[\operatorname{tansig}\left(\mathrm{w}_{\mathrm{i}} \times \mathrm{ln}_{\mathrm{k}}+\mathrm{b}_{1}\right)\right]\right)$

Where $\mathrm{s}$ is the number of neurons in the hidden layer $(S=9)$, $k$ is the number of neurons in the input layer $(K=9), 1$ is the number of neurons in the output layer $(1=1), w_{i}, w_{o}$ and, are weights and $b_{1 s}$ bías, respectively. Equation (5) is not complex because it is composed of a simple arithmetic operation. Therefore, it can be used for online applications.
As well as for the application of reference evapotranspiration estimation. In this work, RNA of multilayer direct feeding was used. The RNA was trained using the forward propagation algorithm. All calculations were performed with MATLAB software with the RNA toolbox.

\subsubsection{Learning neural networks}

A learning (or training) algorithm is defined as a procedure that consists of adjusting the coefficients of a network, to minimize an error function (usually a quadratic) between the outputs of the network, for a given set of inputs, and the desired outputs. (Rumelhart, Hinton, \& Williams, 1986)

To determine the best backpropagation training algorithm, backpropagation algorithms were studied. In addition, three neurons in the hidden layer were used for all retro propagation algorithms. Table 3 shows a comparison of different training algorithms. The LevenbergMarquad backpropagation algorithm was found to be faster than other algorithms because it was designed at the second-order training speed without having to calculate the Hessian matrix, so when the performance function has the form of a sum of squares, then the Hessian matrix can be approximated as:

$H=J^{T} J$

And the gradient can be taken as:

$g=J^{T} e$

where $\mathrm{J}$ is the Jacobian matrix containing the first derivatives of the any error with respect to weights and bias, and is a $e$ vector, while the Jacobian matrix can be calculated through a standard retro propagation technique that is much less complex than the Hessian matrix.

Levenberg Marquardt's algorithm uses this approximation in the Hessian matrix in the following Newton-like equation:

$x_{k+1}=x_{k}-\left[J^{T} J+\mu I\right]^{-1} J^{T} e$

When the scalar $\mu$ is zero, this is just Newton's method, using the approximate Hessian matrix. When $\mu$ is large, it becomes a gradient descended between with a small step size. 
Newton's method is more efficient and accurate and with minimal error, so the goal is to switch to Newton's method as quickly as possible, ( Hagan \& Menhaj, 1994) (HernándezPérez, Garcia-Alavarado, Trystram, \& Heyd, 2004)so when $\mu$ is reduced, after each successful step (reduction in performance function) and is increased only when a tentative step would increase the performance of the function. In this context, the performance function is always reduced in each iteration of the algorithm. So, for this reason, the Levenberg-Marquardt training algorithm was considered in the present study.

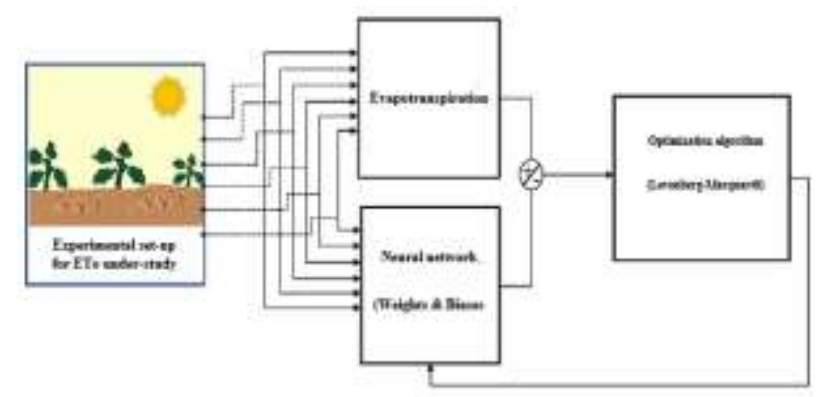

Figure 1 Neural network architecture recurrent to ETo values

Source (El Hamzaoui, y otros, 2011)

\begin{tabular}{|c|c|c|c|c|c|c|}
\hline $\begin{array}{l}\text { Forward- } \\
\text { backpropagation } \\
\text { algorithm }\end{array}$ & Function & Rmse & Epoch & $\begin{array}{l}\text { Correlation } \\
\text { coefficient }\end{array}$ & $\begin{array}{l}\text { Best linear } \\
\text { equation }\end{array}$ & $\begin{array}{l}\text { Cpu } \\
\text { time }\end{array}$ \\
\hline $\begin{array}{l}\text { Levenberg- } \\
\text { marquardt } \\
\text { backpropagation }\end{array}$ & Trainlm & 0.00215 & 1000 & 0.9999 & & \\
\hline $\begin{array}{l}\begin{array}{l}\text { Batch } \\
\text { descent }\end{array} \\
\text { gradient }\end{array}$ & Traingd & 0.01657 & 2000 & 0.9888 & $\mathrm{Y}=0.986 \mathrm{~T}+0.927$ & 135 \\
\hline $\begin{array}{lr}\text { Batch } & \text { gradient } \\
\text { descent } & \text { with } \\
\end{array}$ & $\begin{array}{l}\text { Traingdm } \\
\end{array}$ & 0.01982 & 2000 & 0.987 & $\mathrm{Y}=0.988 \mathrm{~T}+0.837$ & 175 \\
\hline $\begin{array}{l}\text { Polak-ribiere } \\
\text { conjugate gradient } \\
\text { backpropagation }\end{array}$ & Traincgp & 0.03267 & 2000 & 0.979 & $\mathrm{Y}=0.957 \mathrm{~T}+2.53$ & 227 \\
\hline $\begin{array}{l}\text { Scaled conjugate } \\
\text { gradient } \\
\text { backpropagation }\end{array}$ & $\begin{array}{l}\text { Trainscg } \\
\end{array}$ & 0.44944 & 2000 & 0.974 & $\mathrm{Y}=1.020 \mathrm{~T}+0.783$ & 295 \\
\hline $\begin{array}{l}\text { 8fgs quasi-newton } \\
\text { backpropagation }\end{array}$ & $\begin{array}{l}\text { Trainbfg } \\
\end{array}$ & 0.48621 & 2000 & 0.971 & $\mathrm{Y}=0.982 \mathrm{~T}+1.23$ & 383 \\
\hline 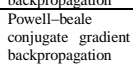 & Traincgb & 0.50821 & 2000 & 0.965 & $\mathrm{Y}=0.960 \mathrm{~T}+2.03$ & 497 \\
\hline $\begin{array}{l}\text { One step secant } \\
\text { backpropagation }\end{array}$ & $\begin{array}{l}\text { Trainoss } \\
\end{array}$ & 0.02754 & 2000 & 0.872 & $\mathrm{Y}=0.617 \mathrm{~T}+45.3$ & 646 \\
\hline $\begin{array}{l}\text { Fletcher-reeves } \\
\text { conjugate gradient } \\
\text { backpropagation }\end{array}$ & Traincgf & 0.01757 & 2000 & 0.782 & $\mathrm{Y}=0.425 \mathrm{~T}+34.8$ & 839 \\
\hline \begin{tabular}{|l}
$\begin{array}{l}\text { Variable learning } \\
\text { rate } \\
\text { backpropagation }\end{array}$ \\
back
\end{tabular} & $\begin{array}{l}\text { Traingdx } \\
\end{array}$ & 0.020397 & 2000 & 0.718 & $\mathrm{Y}=0.386 \mathrm{~T}+38$ & 1090 \\
\hline
\end{tabular}

Table 2 Comparison of 10 backpropagation algorithms with 3 neurons algorithms for neurons in hidden layer Source (El Hamzaoui, y otros, 2011)

However, the performance of the ANN model was statistically measured by the root of the mean square error (RMSE) and the regression coefficient, which are calculated with the experimental values and predictions of the network. These calculations are used as a criterion for the adequacy of the model (see Fig.2), obtained as follows:

$R M S E=\frac{\sqrt{\sum_{q=1}^{Q}\left(\left(y_{q, p r e d}-y_{q, \exp }\right)^{2}\right)}}{\sqrt{Q}}$

$$
R^{2}=1-\frac{\sum_{q=1}^{Q}\left(y_{q, p r e d}-y_{q, \text { exp }}\right)^{2}}{\sum_{q=1}^{Q}\left(y_{q, \exp }-y_{m}\right)^{2}}
$$

Where $\mathrm{Q}$ is the number of data, $y_{q, p r e d}$ is the prediction of the network. $y_{q, \text { exp }}$ is the experimental answer, and $\mathrm{m}$ is the average of the real values, is an index of $y_{q}$ data. Accordingly, RMSE was used as the error function that measures the performance of the neural network. Therefore, the network that has minimum and maximum RMSE was selected as the best $R^{2}$ ANN model.

As mentioned above the input variables of the network are the season of the year (spring, summer, autumn, winter), the date of measurement, the maximum temperature, the minimum temperature, average temperature and the incident solar radiation and the experimental response is evapotranspiration, the characteristics of the variables are found in table 2.

\begin{tabular}{|l|r|}
\hline Variable input & Variable range \\
\hline Season & $0.1-0.4$ \\
\hline Date & no rank \\
\hline $\mathrm{T}_{\max }$ & $28-35$ \\
\hline $\mathrm{T}_{\min }$ & $24-27$ \\
\hline $\mathrm{T}_{\mathrm{prom}}$ & $24-35$ \\
\hline $\mathrm{R}_{\mathrm{s}}$ & $10.9-16$ \\
\hline $\mathrm{ET}_{\mathrm{o}}$ & $0-200$ \\
\hline
\end{tabular}

Table 3 Input variables for the neural network Source Own Source

The architecture of the ANN is determined by the number of layers, the number of nodes and the type of transfer functions, the optimization of the topology of the ANN, in this process is a very important step in the development of a neural network model.

\section{Results and discussion \\ 3.1 Statistical analysis}

The basic description of the collected experimental data as evapotranspiration, incident radiation, average daily temperature, minimum temperature, maximum temperature, season and measurement date, used in the further analysis is summarized in table. The data analysis tool of MS-Excel was used in the calculation of the mean, standard deviation, median, min and max including variable type characteristics are shown in table 4. 


\begin{tabular}{|l|c|r|r|r|r|r|}
\hline $\begin{array}{l}\text { Feature } \\
\text { name }\end{array}$ & \multicolumn{2}{|c|}{$\begin{array}{l}\text { Variable } \\
\text { type }\end{array}$} & Mean & \multicolumn{3}{|c|}{ StdDev } \\
\hline Evaporation & Numeric & 4.62 & 2.41 & 4.61 & 1 & 64.84 \\
\hline $\begin{array}{l}\text { Incident } \\
\text { radiation }\end{array}$ & Numeric & 0.03 & 0.01 & 0.03 & 0.03 & 0.37 \\
\hline $\begin{array}{l}\text { Average } \\
\text { daily } \\
\text { temperature }\end{array}$ & Numeric & 27.01 & 2.70 & 27.50 & 14.50 & 35 \\
\hline $\begin{array}{l}\text { Minimum } \\
\text { temperatura }\end{array}$ & Numeric & 22.03 & 2.71 & 22.10 & 9 & 31 \\
\hline $\begin{array}{l}\text { Maximum } \\
\text { temperatura }\end{array}$ & Numeric & 32 & 3.39 & 32 & 18 & 45 \\
\hline Season & Numeric & 0.24 & 0.11 & 0.20 & 0.10 & 0.40 \\
\hline $\begin{array}{l}\text { Measuremen } \\
\text { t date }\end{array}$ & Categorical & $1977-$ & 11565.45 & $1990-$ & $1926-$ & $2018-$ \\
& $02-19$ & Days & $06-15$ & $12-01$ & $12-31$ \\
\hline
\end{tabular}

Table 4 Sample statistics of the input-outputs variables vectors

Source Own Source

\subsection{Neural network analysis}

The ANN is used in predictive modeling of evapotranspiration using dependent variables as incident radiation, average daily temperature, minimum temperature, maximum temperature, season and measurement date.

Specifically, the ANN structure of $6 \times$ $3 \times 1$, using the LM training algorithm, ANN achieved its optimal performance at 912 iterations, and $\mu=0.0001$. A random approach was used in data division (70\%Training; $15 \%$ Validation; $15 \%$ Testing) and the mean square error (MSE) measure was used in the evaluation of the performance of ANN. The best validation performance of ANN has been achieved at the 900 training iterations (MSE equal to 0.0016) (see. Graph 1).

The error histogram with 20bins is shown in Graph 2. However, the results of the LMANN approach during the training, validation, testing and overall, in the estimation of evapotranspiration using its dependent parameters are shown in Graph. 6, with high coefficient correlation (R2>0.999). Based on the results, we can conclude the following, the network was tested and validated by comparing its predicted output values with the experimental data using an independent set of data. According, to ANN's results, it is possible to simulate the evapotranspiration where input parameters are well known

\subsection{Parameters of neural networks}

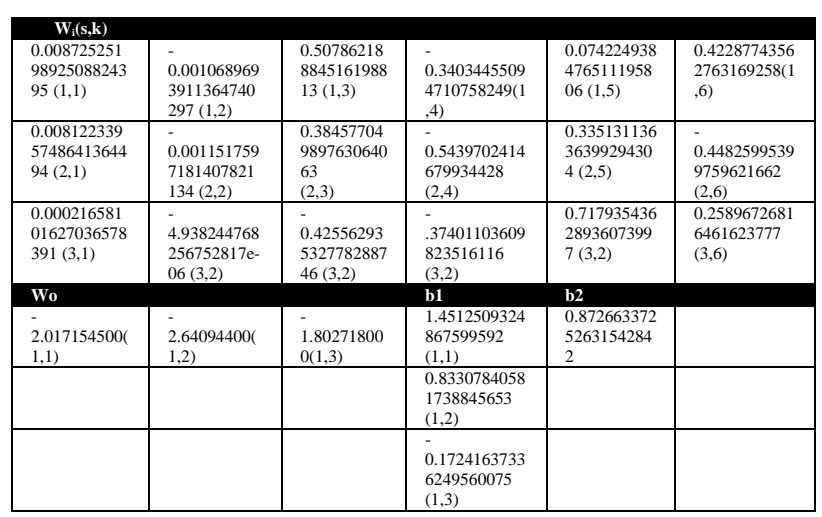

Table 5 Weights and bias of neural network model Source Own Source

Where $\mathrm{s}$ is the number of neurons in the hidden layer $(S=6), k$ is the number of the input $(\mathrm{K}=6)$, and $\mathrm{W}$ and $\mathrm{b}$ are weight and bias, respectively

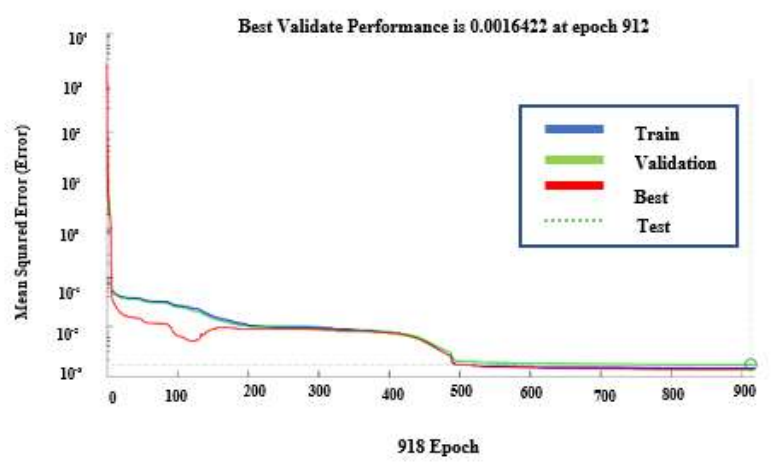

Graph 1. Performance analysis of LM-ANN in terms of validation efficiency

Source (Own source)

The training process is very fast and lasts a very short time. Below is the histogram and the regression graphs obtained (see Figure 4)

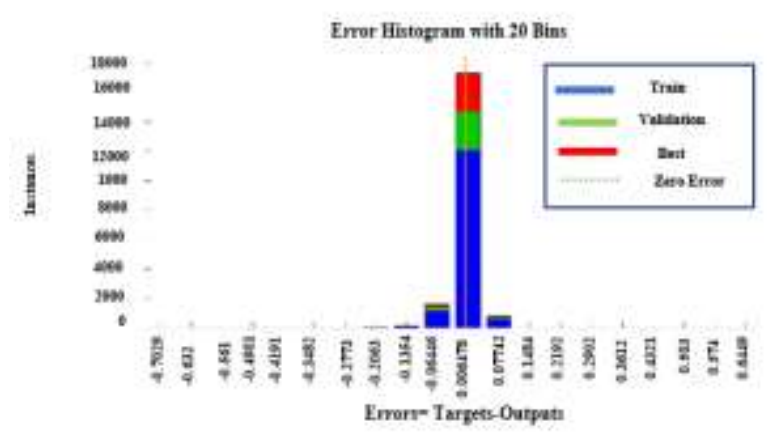

Graph 2 Performance analysis of LM-ANN in terms of error histogram

Source (Own Source)

The histogram shows that most results have an error around 0.006478 . 
The regression graph shows the correlation that exists between the target data and the data provided by the neural network. So, the closer this data is to the straight line, the better the results will be, and better will be the predictions (see Graph 3).
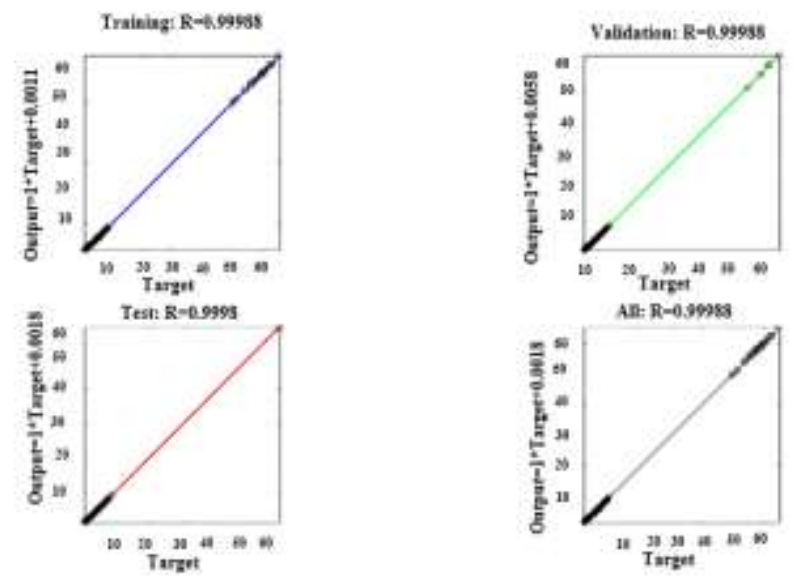

Graph 3 Performance of LM-ANN in the prediction of evapotranspiration using dependent

Source (Own source)

\section{Cost function (target function)}

$E T_{O}=\sum_{s=1}^{S}\left[W_{o(1, s)}\left(\frac{2}{1+\exp \left(-2\left(\sum_{k=1}^{K}\left(W_{i(s, k)} \operatorname{In}_{(k)}\right)+b 1_{(s)}\right)\right)}-\right.\right.$

1) $]+b 2_{(l)}$

$E T_{o}=2\left[\frac{w_{o(1,1)}}{1+e^{x_{1}}}+\frac{w_{o(1,2)}}{1+e^{x_{2}}}+\frac{w_{o(1,3)}}{1+e^{x_{3}}}+\frac{w_{o(1,4)}}{1+e^{x_{4}}}+\right.$

$\left.\frac{w_{o(1,5)}}{1+e^{x_{5}}}+\frac{w_{o(1,6)}}{1+e^{x_{6}}}\right]-\left(w_{o(1,1)}+w_{o(1,2)}+\right.$

$\left.w_{o(1,3)}\right)+b 2_{(l)}$

Where:

$x_{1}=-2\left(w_{i(1,1)} v_{1}+w_{i(1,1)} v_{2}+w_{i(1,1)} v_{3}+\right.$

$\left.w_{i(1,1)} v_{4}+w_{i(1,1)} v_{5}+w_{i(1,1)} v_{6}+b_{1(1)}\right)$

$x_{2}=-2\left(w_{i(2,1)} v_{1}+w_{i(2,2)} v_{2}+w_{i(2,3)} v_{3}+\right.$

$\left.w_{i(2,4)} v_{4}+w_{i(2,5)} v_{5}+w_{i(2,6)} v_{6}+b_{1(2)}\right)$

$x_{3}=-2\left(w_{i(3,1)} v_{1}+w_{i(1,1)} v_{2}+w_{i(1,1)} v_{3}+\right.$

$\left.w_{i(1,1)} v_{4}+w_{i(1,1)} v_{5}+w_{i(1,1)} v_{6}+b_{1(3)}\right)$

\section{Conclusions}

This paper presents a strategy that considers the modeling of evapotranspiration and estimates the operating conditions during the process of plant transpiration and soil evaporation by means of artificial neural networks. The results obtained were satisfactory since the neural algorithm adequately models the evapotranspiration behavior.
Likewise, it has been observed that the Levenberg Marquardt method makes the network parameters converge faster to their weights and bias values. Therefore, this tool is powerful and flexible, since it allows evaluating what would happen in the system if one or the other alternative were taken, without affecting the real system.

Possible future work, perform a simulator implemented in MATLAB using inverse neural networks to validate the predictions by the algorithm, make a comparison between real data and those predicted by the algorithm, it is considered to make a physical prototype to be applied to an irrigation system and check the effectiveness of the algorithm proposed in this research work.

\section{Acknowledgements}

We are grateful to CONACYT for the grant given to Agustin-Ramirez Marco Antonio to support his Master Studies

\section{References}

Aleboyeh, A., Kasiri, M., \& Olya, M. (2011). Prediction of azo dye. Elsevier, 288-294.

Agricultura, G. (15 de marzo de 2020). Obtenido de https://www.inegi.org.mx., 2020: https://www.inegi.org.mx., 2020

al., A. e. (1998).

Allen GR, P. L. (2006). Guías para la determinación de los requerimientos de agua de los cultivos. FAO. Roma., 298.

Allen, e. (1998). Cálculo de la Evapotranspiración Potencial mediante la ecuacion Hargreaves.

CEDRSSA. (19 de 08 de 2021). Centro deEstudios para el desarrollo Rural Sustentable y la Soberania Alimentaria. Obtenido de Blog de opinión: http://www.cedrssa.gob.mx/post_el_n-sector_agropecuario_en_el_pib-n-_segundo_trimestre_de_2019-_htm

Cervantes-Osornio, R. (2013). Modelos Haragreaves Pristley-Taylor y redes neuronales artificiales en la estimacion de la evapotranspiracion de referencia. Ingenieria Investigacion y Tecnología, 166-167. 
CONAGUA, 2. (2020). "ESTADÍSTICAS A PROPÓSITO DEL DÍA MUNDIAL DEL AGUA. Obtenido de https://www.inegi.org.mx/.

Conagua, C. N. (2018). Estadisticas del agua en Mexico. Mexico.

CONAGUA, S. (12 de 04 de 2020). /estacionesmeteorologicas-automaticas. Obtenido de https://smn.conagua.gob.mx/es/estacionesmeteorologicas-automaticas

Cruz, P. P. (2010). Inteligencia Artificial con aplicaciones a la ingenría. alfaomega.

Despange, F., \& Massart, D. (1998). Neural network in multivariate calibration . the analyst, 65-73.

Diaz Cordero, G. (2012).

El Hamzaoui, Y., Hernaández, J., Silva Martinez, S., Bassam, A., Álvarez, A., \& Lizama-Bahena, C. (2011). Rendimiento óptimo de la eliminación de DQO durante el tratamiento acuoso de herbicidas comerciales alazine y gesaprim mediante red neuronal directa e inversa. Desalinizacion, 277(1-3),325-337.

FAO. (1977). Las necesidades de agua en los cultivos.

FAO56. (2021). Evapotranspiracion del cultivo.

G.H, H., \& Z. A, S. (1985). Reference crop evapotranspiration from temperature. Applied Enginnering in Agriculture. 96-99.

G.Liakos, K. (2018). Machine Learning in Agricultura: A Review. Sensors.

García , L., Parra, L., Jimenez, J. M., Lloret, J., \& Lorentz, P. (2020). IoT-Based smart Irrigation Systems An Overview on the recent trends on sensors and IoT systems for Irrigation in precision Agriculture. Sensors, 2-36.

Gómez-Oliver, L. (2020). El papel de la agricultura en el desarrollo de México.

Gonzalez-Camacho, J. M. (2008). Prediccion de la evapotranspiracion de referencia mediante redes neuronales artificiales.

Grillo F., M., I. A., \& Sc., M. (1971). Determinacion de la evapotranspiracion con lisimetros.
Hernández-Pérez, J., Garcia-Alavarado, M., Trystram, G., \& Heyd, B. (2004). Neural networks for the heat and mass transfer predicction during drying of cassava and mango. Innovative Food Science and Emerging Technology, 57-64.

H. \& Beale, D. (2001). Neural Network Toolbox. For Use with Matlab. User's Guide (version 4). Natick.

Hagan, M., \& Menhaj, M. (1994). Training feedforward networks with the Marquardt algorithm, IEEE Transactions on Neural Network. 989-362.

Kumar, M. (2002). Estimacion de la evapotranspiración utilizando una red neuronal artificial. Journal of irrigation and Drainage Engineering.

Liankos, K. G., Busato, P., Moshou, D., \& Pearson, S. (2018). Machine Learning in Agriculture: A review. Sensors.

Limin, F. (1994). Neural Networks in Computer Intelligence. McGraw-Hill.

Mahajan, Y. (2018). Automation by IOT and Machine Learinig Irrigation. IJARIIE.

O. Lucas, P. (2018). Uso de una red neuronal artificial para estimar la evapotranspiracion de referencia. Global Science and Tecnology.

POBLACION, I. (25 de enero de 2020). https://inegi.org.mx/temas/estructura/.

Obtenido de

https://www.inegi.org.mx/temas/estructura/

Poma, D. (2010). Stock Price Prediction using neural Networks. 2,3.

Rumelhart, D., Hinton, G., \& Williams, R. (1986). Learning internal representations by error propagation ,Parallel Data Processing 1. 318-362. 